\title{
FAKTOR IBU DAN ANAK, POLA MAKAN, ASUPAN ZAT GIZI DAN RIWAYAT INFEKSI PADA ANAK STUNTING USIA 6-23 BULAN DI WILAYAH KERJA PUSKESMAS I WANGON KABUPATEN BANYUMAS
}

\section{FACTORS MOTHER AND CHILD, DIET, NUTRITION AND THE HISTORY OF THE SUBSTANCE INTAKE INFECTIONS IN CHILDREN AGE 6-23 MONTHS STUNTING WORKING IN THE HEALTH DISTRICT I WANGON BANYUMAS}

\author{
Era Yunianingsih ${ }^{1}$, Kun Aristiati ${ }^{2}$, Sunarto ${ }^{3}$
}

\begin{abstract}
Background : Toddlers Stunting prevalence in Central Java in 2016 as much as $18.1 \%$. Stunting prevalence in Puskesmas I Wangon in 2016 as much as 27.12\%. Factors Mother and Child, Diet, Nutrition and Substance Intake Infection history is an important indicator Stunting cause.
\end{abstract}

Objective : Explain relationship Mother and child factors, diet, nutrient intake and a history of infection the incidence of stunting in children aged 6-23 months working area of Puskesmas I Wangon Wangon District of Banyumas.

Method : Including public nutrition research with case control approach. The research sample is Children aged 6-23 months was 50 with the distribution of 25 cases and 25 controls. Retrieval of data including data according to the nutritional status of mother and child factors, Diet, Nutrition and History Intake Infectious Substances.

Results: Stunting of children aged 6-23 months with less energy intake of 15 (60\%), protein intake is less than 6 (24.0\%), calcium intake of less than $17(68.0 \%)$, zinc intake less than $18(72.0 \%)$, iron intake is less than $20(80 \%)$. Based on the history of stunting baduta infection of $8(32.0 \%)$ had diarrhea, and $11(44.0 \%)$ had respiratory infection. Based on the factors Mother and Child, stunting baduta total of 14 (56.0\%) had a short Mother, 21 (84.0\%) Mother did not work.

Conclusion: Statistical analysis showed no relationship between Height Mom $(p=0.015)$, there was no association between intake of energy, protein, calcium intake, intake of zinc, intake iron, diarrhea, respiratory infections, frequency of consumption, the diversity of food, education, BBL status, Apgar score, gender, occupation Mother and the Family Incomeand.

Keywords : Nutritional status, maternal and child factors, Diet, Nutrition and History Intake Infectious Substance.

\section{ABSTRAK}

Latar belakang: Prevalensi Balita Stunting di Jawa Tengah pada tahun 2016 sebanyak 18,1\%. Prevalensi Stunting di Wilayah Kerja Puskesmas I Wangon pada tahun 2017 sebanyak 27,12\%. Faktor Ibu dan Anak, Pola Makan, Asupan Zat Gizi dan Riwayat Infeksi merupakan indikator penting penyebab Stunting .

Tujuan Penelitian : Menjelaskan hubungan faktor Ibu dan anak, pola makan, asupan zat gizi dan riwayat infeksi dengan kejadian stunting pada anak usia 6-23 bulan wilayah kerja puskesmas I Wangon Kecamatan Wangon Kabupaten Banyumas.

Rancangan Penelitian : Termasuk penelitian gizi masyarakat dengan pendekatan Case Control. Sampel penelitian ialah Anak usia 6-23 bulan berjumlah 50 dengan pembagian 25 kasus dan 25 kontrol. Pengambilan data meliputi data status gizi menurut Faktor Ibu dan Anak, Pola Makan, Asupan Zat Gizi dan Riwayat Infeksi.

Hasil : Anak usia 6-23 bulan stunting dengan asupan energi kurang 15(60\%), asupan protein kurang 6(24,0\%), asupan kalsium kurang 17 (68,0\%), asupan zink kurang 18(72,0\%), asupan zat besi kurang 20(80\%). Berdasarkan riwayat infeksi baduta stunting sebanyak $8(32,0 \%)$ mengalami diare, dan sebanyak $11(44,0 \%)$ mengalami ISPA. Berdasarkan faktor Ibu dan Anak, baduta stunting sebanyak $14(56,0 \%)$ memiliki Ibu pendek, $21(84,0 \%)$ Ibu tidak bekerja. 
Simpulan : Hasil analisis statistik menunjukkan ada hubungan antara Tinggi Badan Ibu $(p=0,015)$, dan tidak ada hubungan antara asupan energi, asupan protein, asupan kalsium, asupan zink, asupan zat besi, diare, ISPA, frekuensi makan, keragaman makanan, pendidikan, status BBL, nilai APGAR, jenis kelamin, pekerjaan Ibu dan pendapatan keluarga.

Kata kunci : Status Gizi, Faktor Ibu dan Anak, Pola Makan, Asupan Zat Gizi dan Riwayat Infeksi

\section{PENDAHULUAN}

Riset Kesehatan Dasar (Riskesdas) 2013 menunjukkan stunting pada balita masih cukup serius dimana prevalensi pendek tahun 2013 sebanyak 37,2 persen. Hasil ini meningkat jika dibandingkan tahun 2010 (35,6\%) dan 2007 (36,8\%) 123 . Menurut hasil Pemantauan Status Gizi balita (PSG) di Jawa Tengah tahun 2016 menunjukkan prevalensi balita stunting sebanyak 18,1 persen ${ }^{4}$. Sementara itu, di Kabupaten Banyumas tahun 2016 ditemukan (18,8\%) balita stunting dan (12,82\%) diantaranya adalah anak usia 6-23 bulan ${ }^{5}$. Berdasarkan hasil screening menunjukkan anak bawah dua tahun (baduta) menunjukkan 291 anak $(27,12 \%)$ mengalami stunting dari 1073 baduta yang dilakukan screening pada bulan Maret 2017, angka tersebut lebih tinggi dibandingkan prevalensi stunting di Kabupaten Banyumas dan Jawan Tengah.

Stunting menjadi ukuran utama dari masalah kurang gizi pada anak karena tingginya angka prevalensi dan beratnya dampak yang terjadi sepanjang daur kehidupannya baik pada jangka pendek maupun jangka panjang ${ }^{6}$. Efek jangka pendeknya meliputi meningkatkan kesakitan, ketidakmampuan, dan kematian ${ }^{7}$. Sedangkan efek jangka panjang, yaitu berupa reduksi ukuran tubuh, kemampuan intelektual, produktivitas ekonomi, kemampuan reproduksi, serta meningkatnya risiko penyakit metabolik dan penyakit jantung ${ }^{8}$.

WHO (2014) menyatakan bahwa "Stunting results from causes that extend beyond hunger and food availability" yang berarti bahwa kejadian stunting disebabkan oleh kelaparan dan ketidaktersediaan pangan ${ }^{9}$. Berdasarkan kerangka konsep UNICEF, asupan makan salah satu komponen ketersediaan pangan yang mencakup aspek kuantitas dan kualitas. Dari aspek kuantitas dapat diukur dengan jumlah ketersediaan pangan dalam bentuk energi/kapita/hari, sedangkan kualitas dapat diukur dari keberagaman makanan (dietary diversity) yang tersedia di tingkat rumah tangga yang diukur berdasarkan apa yang dikonsumsi oleh keluarga dalam 24 jam terakhir (24-hour recall) dan meliputi 7 (tujuh) kelompok makanan ${ }^{10}$.

Hasil penelitian menunjukkan bahwa prevalensi keseluruhan praktek pemberian makan anak yang tepat sangat rendah yaitu $9,5 \%(95 \% \mathrm{Cl}$ = 7,0-12,0, 57/611), hal ini akan memberikan dampak negatif pada status gizi anak, keluarga merupakan faktor yang dapat meningkatkan praktik pemberian makanan tambahan yang sesuai. selain dari pola pemberian makan keluarga, terdapat hubungan antara riwayat status BBLR $(p=0,015)$ dengan kejadian pendek pada anak usia 6-24 bulan ${ }^{11}$. Anak dengan berat badan lahir yang rendah memiliki risiko 5,87 kali untuk mengalami kejadian pendek $^{12}$. ( Rahayuh dkk, 2016). Indikator antropometrik ibu, asupan anak meliputi energi dan kalsium serta sosiodemografi secara signifikan terkait dengan panjang anak-anak usia 2-24 bulan $^{13}$.

Berdasarkan latar belakang diatas, peneliti tertarik untuk meneliti mengenai faktor lbu dan anak, pola makan, asupan zat gizi dan riwayat infeksi pada anak stunting usia 6-23 bulan di wilayah kerja puskesmas I Wangon Kecamatan Wangon Kabupaten Banyumas.

\section{METODE PENELITIAN}

Penelitian ini merupakan kajian penelitian dibidang gizi masyarakat yang meneliti faktor ibu, pola pemberian makan, asupan zat gizi dan riwayat infeksi dengan kejadian stunting pada anak usia 623 bulan wilayah kerja puskesmas I Wangon. Penelitian ini dilakukan pada bulan Februari sampai Juli 2017. Jenis Penelitian ini yaitu anallitik observasional dengan design case control yang melibatkan 25 baduta stunting (kasus) dan 25 baduta tidak stunting (control).

Populasi dalam penelitian ini adalah seluruh anak usia 6-23 bulan di Puskesmas I Wangon yang berjumlah 1444 baduta. Kriteria inklusi sampel pada kelompok kasus maupun kontrol antara lain baduta lahir di Puskesmas I Wangon, untuk sampel kasus yaitu anak stunting yang memiliki Z-score (<-2 SD) sedangkan sampel kontrol yaitu anak tidak stunting yang memiliki Zscore $\geq 2$ SD. Sementara untuk kriteria eksklusi yaitu anak usia 6-23 bulan mengalami penyakit komplikasi.

Pengambilan data meliputi data identitas sampel, identitas responden, asupan zat gizi, riwayat infeksi, pola pemberian makan, faktor ibu dan anak serta faktor ekonomi. Pengolahan data meliputi editing, skoring, coding, tabulating. Data 
yang diperoleh kemudian diuji secara statistik menggunakan chisquare untuk analisis bivariat, kemudian dilanjutkan dengan analisis multivariat untuk mengetahui variabel determinan terhadap kejadian stunting dengan menggunakan regresi logistik.

\section{HASIL DAN PEMBAHASAN}

\section{A. Karakteristik Subjek Penelitian}

Tabel 1. Karakteristik Subjek Penelitian pada Kelompok Stunting dan Tidak Stunting pada anak usia 6-23 bulan di Wilayah Kerja Puskesmas I Wangon Tahun 2017

\begin{tabular}{|c|c|c|c|c|c|c|}
\hline \multirow[t]{2}{*}{$\begin{array}{c}\text { Karakteristik Subjek } \\
\text { Penelitian }\end{array}$} & \multicolumn{2}{|c|}{ Stuntine } & \multicolumn{2}{|c|}{$\begin{array}{l}\text { Tidak } \\
\text { Stunting }\end{array}$} & \multicolumn{2}{|c|}{ Total } \\
\hline & $n$ & $x$ & $n$ & $\mathrm{~s}$ & $n$ & $x$ \\
\hline \multicolumn{7}{|l|}{ Umur Anak. } \\
\hline 6. 11 bulan & 3 & 1200 & 2 & $B, 0$ & 5 & 10,0 \\
\hline $12-23$ bulan & 22 & 88,0 & 23 & 92,0 & 45 & 90,0 \\
\hline \multicolumn{7}{|l|}{ Jenis Kelamin } \\
\hline Laki-laki & 13 & 52,0 & 11 & 44,0 & 24 & 48,0 \\
\hline Perempuan & 12 & 180 & 14 & 56,0 & 26 & 52,0 \\
\hline \multicolumn{7}{|l|}{ Umur lbes } \\
\hline e 20 taturin & 1 & 40 & 0 & 0,0 & 1 & 2,0 \\
\hline 20.35 tahun & $n$ & 84,0 & 21 & 84,0 & 42 & 84,0 \\
\hline$>35$ tahun & 3 & 12,0 & 4 & 16,0 & 7 & 14,0 \\
\hline \multicolumn{7}{|l|}{ Pendidikan lbu } \\
\hline Tidak Sekolah & 2 & 8.0 & 0 & 0.0 & 2 & 4,0 \\
\hline Dasar (Tamat SO \& SMP) & 19 & 76,0 & 17 & 68,0 & 36 & 72,0 \\
\hline Menergah (Tamat SMA) & 3 & 12,0 & 8 & 32,0 & 11 & 22,0 \\
\hline Atas (Tamat $011 / / 51 / 52$ dst) & 1 & 4,0 & 0 & 0,0 & 1 & 2,0 \\
\hline \multicolumn{7}{|l|}{ Pekerjaan lbu } \\
\hline Tidak Bekerja & 20 & 200 & 21 & 84,0 & 41 & 82,0 \\
\hline Pegawat & 1 & 4,0 & 1 & 4,0 & 2 & 4,0 \\
\hline Pedapaing & 0 & 0,0 & 1 & 4,0 & 1. & 2,0 \\
\hline Lainmra & $A$ & 16,0 & 2 & 8,0 & 6 & 12,0 \\
\hline
\end{tabular}

Hasil penelitian memperlihatkan bahwa sebagian besar subjek berumur 12-23 bulan $(90,0 \%)$ dan sebanyak $52,0 \%$ diantaranya berjenis kelamin perempuan. Sebagian besar umur Ibu yaitu berkisar 20 - 35 tahun sebanyak $84,0 \%$. Pendidikan Ibu sebagian besar hanya lulusan sekolah dasar (SD) dengan persentase $72,0 \%$.Pekerjaan kedua Ibu umumnya adalah tidak bekerja yaitu sebanyak $82,0 \%$.

\section{B. Analisis Analitik}

Tabel 2. Hubungan Variabel Independent dengan kejadian Stunting Anak Usia 6-23 Bulan di Wilayah Kerja Puskesmas I Wangon Tahun 2017

\begin{tabular}{|c|c|c|c|c|}
\hline \multirow{2}{*}{$\begin{array}{l}\text { Karaktaristik: } \\
\text { Subjek Penelitian }\end{array}$} & \multicolumn{3}{|c|}{ An adjusted } & \multirow{2}{*}{ Adjusted } \\
\hline & OR [95 a) & $p$ & or (9s5 al) & \\
\hline \multicolumn{5}{|l|}{ ASUPAN ZAT GIZI } \\
\hline Aupan Energi & $1,9 \mid 0,6,5,8)$ & 0,258 & $1,4(0,1-19,1)$ & 0,809 \\
\hline Ascan Pratein & $1,0|0,3-3,7\rangle$ & 1,000 & $1,9(0,4-35,6)$ & $0, E A 1$ \\
\hline Asupan Catsium & $0,5(0,1-1,9)$ & 0,333 & $0,4(0,0-7,8)$ & 0,571 \\
\hline Asupan Zink & $1,7)(0,5-5,6)$ & 0,320 & $6,5 / 0,3-126,7)$ & 0,225 \\
\hline Aswapan Zat tess & $1,6(0,4-5.9)$ & 0,500 & $0,1(0,0-2,4)$ & 0.125 \\
\hline \multicolumn{5}{|l|}{ AWAYAT INFEKSI } \\
\hline Dare & $2.510,6-9,6)$ & 0,185 & $0,5(0,0-7,1)$ & 0,635 \\
\hline ISPA & $4,1\{1,1-15,6\}$ & tount & $0,9(0,1-13,2)$ & 0,946 \\
\hline \multicolumn{5}{|l|}{$\begin{array}{l}\text { POUA PEMBERUAN } \\
\text { MAKAN }\end{array}$} \\
\hline Frekuensi Makan & $1,2\{0,43,9\}$ & 0,765 & $3,9(0,1110,5)$ & 0,418 \\
\hline Keragamin Paryen & $2,3 \mid 0,6-8,2)$ & 0,208 & $1,5 \mid 0,1-23,5\}$ & 0,779 \\
\hline \multicolumn{5}{|l|}{$\begin{array}{l}\text { FAKTOR IBU DAN } \\
\text { ANLAK }\end{array}$} \\
\hline Th the & $30,5(3,5,262,3)$ & 0,000 & $0,0(0,0-0,3)$ & 0,017 \\
\hline Pendidikan ibu & $5,4\{1,0.28,0\}$ & 0.034 & $0,6(0,0-14,13$ & 0,718 \\
\hline Pekeriann itui & $10(0,2-4,5\}$ & 1,000 & $1,3(0,0-50,7)$ & 0.25 \\
\hline Status Bbi & - & 0,490 & " & 1000 \\
\hline NILI APGAR & - & 1,000 & - & 1000 \\
\hline $\begin{array}{l}\text { Jenis Kelamin } \\
\text { FAKTOR EROMOMI }\end{array}$ & $0,7\{0,2: 2,2\}$ & $0,5 \pi$ & $7,8\{0,5-105\}$ & 0.121 \\
\hline Pendupatan & $4,1[1,0-15,6\}$ & 0,031 & $0,90,1-13,2\rangle$ & 0,052 \\
\hline
\end{tabular}

\section{PEMBAHASAN}

Berdasarkan analisis bivariat, terdapat 4 variabel yang berhubungan dengan kejadian stunting yaitu riwayat infeksi ISPA, TB Ibu, pendidikan dan pendapatan. Karena berdasarkan teori semua variabel independen berpengaruh, maka semua variabel digunakan dalam analisis multivariat. Setelah dilakukan analisa multivariat dari enam belas variabel independent yang dihubungkan dengan kejadian stunting anak baduta di wilayah kerja Puskesmas I Wangon hanya terdapat 1 variabel yang menunjukkan hubungan yang signifikan yaitu variabel TB ibu dengan $p$ value $\leq 0,05$. Sedangkan variabel lainnya yaitu asupan energi, asupan protein, asupan kalsium, asupan zink, asupan zat besi, diare, ISPA, frekuensi makan, keragaman makanan, pendidikan, status BBL, nilai APGAR, jenis kelamin, pekerjaan ibu dan pendapatan keluarga tidak menunjukkan hubungan yang signifikan dengan kejadian stunting, dimana $p$ value $>0,05$. Proporsi kejadian stunting berbeda pada masing-masing variabel yaitu:

\section{a. Faktor Asupan Zat Gizi}

Proporsi kejadian stunting pada anak baduta yang memiliki asupan energi kurang yaitu sebanyak $60,0 \%$, asupan protein kurang sebanyak 24,0\%, asupan kalsium kurang sebanyak $68,0 \%$, asupan zink kurang sebanyak $72,0 \%$ dan besi kurang sebanyak $80,0 \%$. Hasil analisis menggunakan uji chi square menunjukkan tidak ada hubungan yang signifikan antara asupan zat gizi dengan kejadian stunting, hasil ( $p$ value $>0,05$ ) yang ditunjukkan dengan asupan energi $(p=0,258)$, asupan protein 
$(p=1,000)$, asupan calsium $(p=0,333)$, asupan zink $(p=0,370)$, dan asupan zat besi $(p=0,508)$.

Berdasarkan hasil analisis multivariat menggunakan uji regresi logistik menunjukkan hasil yang sama yaitu tidak terdapat hubungan yang signifikan antara asupan zat gizi dengan kejadian stunting. Hasil uji regresi logistik untuk asupan energi $(p=0,660)$, asupan protein $(p=0,611)$, asupan calsium $(p=0,663)$, asupan zink ( $p=0,361)$, dan asupan zat besi $(p=0,164)$.

Terdapatnya hubungan yang tidak bermakna antara asupan energi, protein, calsium, zink, Fe dengan status gizi kemungkinan disebabkan adanya faktor-faktor lain yang mempengaruhi status gizi seseorang. Faktor tersebut diantaranya adalah aktivitas fisik, konsumsi garam, riwayat penyakit, kebiasaan jajan, yang tidak diteliti dalam penelitian ini.

Ketidaksesuaian hasil penelitian dimana tidak ada hubungan yang bermakna antara asupan protein dengan status gizi stunting pada anak baduta.dengan teori dikarenakan berdasarkan hasil wawancara dalam pola pemberian makan anak masih banyak responden yang belum mengetahui bagaimana teknik yang yang tepat dalam memberikan susu formula, dimana para Ibu mencampurkan langsung susu bubuk dengan air panas atau setelah mendidih. Kemudian terdapat responden yang merebus kembali ASI yang telah disimpan di kulkas hingga mendidih.

ASI tidak boleh dihangatkan menggunakan panas langsung atau microwave karena dapat menimbulkan hot spots dan juga merusak zat gizi khususnya yaitu protein. Mutu protein bergantung pada kemudahannya untuk dicerna dan diserap serta komposisi asam amino didalamnya. Jika asam amino kurang, pertumbuhan jaringan dan organ, berat dan tinggi badan akan terpengaruh ${ }^{14}$. Sedangkan untuk baduta yang mengkonsumsi susu formula perlu diperhatikan dalam persiapannya dimana susu bubuk diberikan dalam jumlah yang tepat sesuai petunjuk pabrikan. Takaran yang salah dapat menimbulkan konstipasi, dehidrasi bahkan malnutrisi. Air yang digunakan untuk melarutkan susu tidak kurang dari $70^{\circ} \mathrm{C}^{15}$. Oleh karena itu, di perlukan persiapan yang tepat dalam pengolahan makanan, karena jika anak konsumsi makanan sumber protein sudah sesuai kebutuhan namun penyerapan dalam tubuh dapat berlangsung tidak optimal dikarenakan persiapan atau pengolahan yang tidak sesuai anjuran.

$$
\text { Hasil penelitian menunjukkan }
$$
ketidaksesuaian dengan teori yang ada dimana status gizi seseorang dapat ditentukan oleh asupan zat gizi yang berasal dari makanan sehari-hari. Zink merupakan salah satu zat gizi mikro yang berguna untuk pertumbuhan tubuh yang normal dan perkembangan manusia, mulai dari masa kehamilan, anak-anak, hingga dewasa, apabila terjadi ketidakseimbangan antara asupan zink dengan kebutuhan maka akan terjadi masalah gizi ${ }^{16}$.

\section{b. Faktor Riwayat Infeksi}

Proporsi kejadian stunting pada anak baduta yang memiliki riwayat diare yaitu sebanyak $32,0 \%$ dan riwayat ISPA yaitu sebanyak 44,0\%.. Hasil analisis menggunakan uji chi square diperoleh riwayat diare $(p=0,185)$ dan riwayat ISPA $(p=0,031)$ artinya tidak ada hubungan yang bermakna antara riwayat diare dengan status gizi stunting pada anak baduta, terdapat hubungan yang bermakna antara riwayat ISPA dengan status gizi stunting pada anak baduta ( $p$ value $\leq 0,05$ ). Setelah dilakukan analisis multivariat menggunakan uji regresi logistik diperoleh riwayat diare $(p=0,695)$ dan riwayat ISPA $(p=0,961)$ artinya tidak ada hubungan yang bermakna antara riwayat diare dan ISPA dengan status gizi stunting pada anak baduta.

Penyakit infeksi tidak berhubungan dikarenakan penilaian penyakit infeksi hanya dalam waktu yang singkat yaitu berdasarkan adanya gejala-gejala penyakit infeksi dalam 1 bulan terakhir sehingga tidak mampu menilaidampak penyakit infeksi pada anak-anak yang diberi MP-ASI dini dan ada kemungkinan terjadinya bias ketika wawancara sehingga dalam penelitian ini tidak ditemukan hubungan yang signifikan.

\section{c. Faktor Pola Pemberian Makan}

\section{1) Hubungan Frekuensi Makan dengan Stunting}

Proporsi kejadian stunting pada anak baduta yang menerapkan frekuensi makan tidak tepat yaitu sebanyak 36,0\%. Hasil analisis menggunakan uji chi square diperoleh $p$ value 0,765 ( $p$ value $>0,05$ ) yang berarti ada hubungan yang tidak signifikan antara frekuensi makan dengan status gizi stunting pada anak baduta. Setelah dilakukan analisis multivariat menggunakan uji regresi logistik diperoleh $p$ value 0,454 ( $p$ value $>0,05$ ) artinya tidak ada hubungan yang bermakna antara frekuensi makan dengan status gizi stunting pada anak baduta. 
Hasil penelitian ini menunjukkan bahwa tidak adanya hubungan yang signifikan antara frekuensi makan dengan stunting anak baduta. Maka dapat disimpulkan bahwa anak baduta stunting bukan disebabkan oleh frekuensi makan yang tidak tepat.

\section{2) Hubungan Jenis Keragaman Pangan dengan Stunting}

Proporsi kejadian stunting pada anak baduta yang menerapkan keragaman pangan yang kurang yaitu sebanyak $36,0 \%$. Hasil analisis menggunakan uji chi square diperoleh $p$ value 0,208 ( $p$ value $>0,05$ ) yang berarti ada hubungan yang tidak signifikan antara keragaman pangan dengan status gizi stunting pada anak baduta. Setelah dilakukan analisis multivariat menggunakan uji regresi logistik diperoleh $p$ value 0,771 ( $p$ value > $0,05)$ artinya tidak ada hubungan yang bermakna antara jenis keragaman pangan dengan status gizi stunting pada anak baduta. Tidak adanya hubungan antara keragaman makanan dan kejadian stunting diduga karena tidak ada perbedaan konsumsi setiap kelompok makanan antara anak stunting dan anak dengan status gizi normal seperti yang sudah dijelaskan sebelumnya.

Berdasarkan hasil penelitian menunjukkan bahwa pola pemberian makan dengan keragaman pangan kurang pada anak mempunyai risiko 0,7 kali untuk mengalami kejadian stunting dibandingkan anak-anak yang diberikan makanan beragam. Konsumsi makanan beragam sangat penting guna mencapai gizi yang seimbang sehingga asupan gizi yang masuk dalam tubuh sesuai dengan kebutuhan. Oleh karena itu pemerintah daerah setempat secara berkelanjutan mendorong pemberdayaan masyarakat untuk penganeka - ragaman pangan melalui program pengembangan kebunkebun keluarga. Pemerintah juga diharapkan dapat membantu dalam pengadaan bibit dan pelatihan bagi pengelolaan lahan. Dinas Kesehatan Kabupaten Banyumas diharapkan dapat membuat program intervensi gizi bagi ibu hamil risiko tinggi termasuk ibu dengan tinggi badan kurang dalam bentuk skrining ibu hamil risiko tinggi untuk selanjutnya diberikan pemahaman seputar kondisi kesehatan mereka dan pemberian informasi seputar gizi selama masa kehamilan. Intervensi gizi bagi anak usia 623 bulan dalam bentuk sosialisasi pedoman gizi seimbang (PGS) yang terbaru kepada ibu-ibu pada jadwal posyandu.

\section{d. Faktor Ibu dan Anak}

\section{1) Hubungan Tinggi Badan lbu dengan Stunting}

Proporsi kejadian stunting pada anak baduta yang memiliki ibu dengan tinggi badan kategori pendek yaitu sebanyak 56,0\%. Hasil analisis menggunakan chi square diperoleh $p$ value 0,000 ( $p$ value $\leq 0,05$ ) yang berarti ada hubungan yang signifikan antara tinggi badan ibu dengan status gizi stunting pada anak baduta.

Analisis multivariat jugan menunjukkan ada hubungan yang signifikan antara tinggi badan ibu dan kejadian stunting pada anak usia 6-23 bulan. Hasil analisis menggunakan uji regresi logistik ganda diperoleh $p$ value 0,017 ( $p$ value $<0,05$ ) yang berarti ada hubungan yang signifikan antara tinggi badan ibu dengan status gizi stunting pada anak usia 6-23 bulan.

Hubungan tinggi badan ibu dan kesehatan bayi dapat dilihat dari dua faktor yaitu faktor keturunandan faktor kesehatan ibu. Salah satu atau keduaorang tua yang pendek akibat kondisi patologi (seperti defisiensi hormon pertumbuhan) memiliki gen dalamkromosom yang membawa sifat pendek. Kondisitersebut memperbesar peluang anak mewarisi gentersebut dan tumbuh menjadi anak pendek. Meskipun demikian, bila orang tua pendek akibat kekurangan zatgizi atau penyakit, kemungkinan anak dapat tumbuhdengan tinggi badan normal selama anak tersebut tidak terpapar faktor risiko lain. Wanita pendekmempunyai tulang pinggul yang lebih sempit. Pada ibu hamil yang pendek terjadi hambatan aliran darah dalam kandungan karena kondisi tersebutsehingga pertumbuhan uterus, plasenta, dan janinpun terhambat .

\section{2) Hubungan Tingkat Pendidikan Ibu dengan Stunting}

Proporsi kejadian stunting pada anak baduta yang memiliki ibu dengan pendidikan rendah yaitu sebanyak $92,0 \%$. 
Hasil analisis menggunakan chi square diperoleh $p$ value 0,034 ( $p$ value $<0,05$ ) yang berarti ada hubungan signifikan antara tinggi badan ibu dengan status gizi stunting pada anak baduta. Namun, setelah dilakukan analisis multivariat tidak menunjukkan ada hubungan yang signifikan antara pendidikan ibu dan kejadian stunting pada anak usia 6-23 bulan. Hasil analisis menggunakan uji regresi logistik ganda diperoleh $p$ value 0,693 ( $p$ value $>0,05$ ) yang berarti tidak ada hubungan yang signifikan antara tinggi badan ibu dengan status gizi stunting pada anak usia 6-23 bulan.

\section{3) Hubungan Status Pekerjaan Ibu dengan} Stunting

Proporsi kejadian stunting pada anak baduta dengan kategori ibu bekerja yaitu sebanyak $84,0 \%$. Hasil analisis menggunakan uji fisher's exact test diperoleh $p$ value 1,000 ( $p$ value $>0,05$ ) yang berarti tidak ada hubungan yang signifikan antara jumlah pekerjaan ibu dengan status gizi stunting pada anak baduta. Analisis multivariat juga menunjukkan tidak ada hubungan yang signifikan antara pekerjaan ibu dan kejadian stunting pada anak usia 6-23 bulan. Hasil analisis menggunakan uji regresi logistik ganda diperoleh $p$ value 0,981 ( $p$ value $<0,05$ ) yang berarti ada hubungan yang tidak signifikan antara pekerjaan ibu dengan status gizi stunting pada anak usia 6-23 bulan.

Hasil penelitian ini menunjukkan bahwa tidak adanya hubungan yang signifikan antara pekerjaan ibu dengan stunting anak baduta, dimana anak stunting lebih banyak terdapat pada ibu yang tidak bekerja dibandingkan dengan ibu yang bekerja.

Hasil ini tidak sejalan dengan penelitian yang dilakukan Mulyono (2000) pada bayi yang menunjukkan adanya hubungan yang signifikan antara pekerjaan ibu dengan status gizi dimana ibu yang bekerja memiliki anak stunting lebih banyak dibandingkan dengan ibu yang tidak bekerja.

Ibu bekerja yang lebih banyak berada di luar rumah akan memiliki lebih banyak penghasilan yang dialokasikan kepada anaknya dan sebaliknya semakin banyak waktu bersama anak (makan dan bermain) maka semakin kecil kesenggangan waktu untuk mencari uang. Kedua hal tersebut yaitu uang dan waktu akan mempengaruhi kualitas status gizi anak.

\section{4) Hubungan Status BBL dengan Stunting} Proporsi kejadian stunting pada anak baduta dengan status BBLR yaitu sebanyak $8,0 \%$. Hasil analisis menggunakan uji fisher's exact test diperoleh $p$ value 0,490 ( $p$ value $>0,05$ ) yang berarti ada hubungan yang tidak signifikan antara status BBL dengan status gizi stunting pada anak baduta. Analisis multivariat juga menunjukkan ada hubungan yang tidak signifikan antara status BBL dengan kejadian stunting pada anak usia 6-23 bulan. Hasil analisis menggunakan uji regresi logistik ganda diperoleh $p$ value 1,000 ( $p$ value $>0,05$ ) yang berarti tidak ada hubungan signifikan antara tinggi badan ibu dengan status gizi stunting pada anak usia 6-23 bulan.

Hasil penelitian ini menunjukkan bahwa tidak adanya hubungan yang signifikan antara status BBL dengan stunting anak baduta. Maka dapat disimpulkan bahwa anak badutastunting bukan disebabkan oleh BBLR.

Hasil ini tidak sesuai dengan hasil penelitian sebelumnya dimana analisis menunjukkan bahwa terdapat hubungan antara BBLR dengan kejadian stunting pada anak usia 6-24 bulan yaitu 5,6 kali lebih berisiko untuk mengalami kejadian stunting pada anak dengan riwayat BBLR dibandingkan anak yang lahir dengan beratbadan normal. Kondisi ini dapat terjadi karena pada bayiyang lahir dengan BBLR, sejak dalam kandungan telahmengalami retardasi pertumbuhan interauterin dan akanberlanjut sampai usia selanjutnya setelah dilahirkan yaitumengalami pertumbuhan dan perkembangan yang lebihlambat dari bayi yang dilahirkan normal dan sering gagalmenyusul tingkat pertumbuhan yang seharusnya dicapaipada usianya setelah lahir ${ }^{17}$.

\section{5) Hubungan Nilai APGAR dengan Stunting}

Proporsi kejadian stunting pada anak badutadengan riwayat asfiksia yaitu sebanyak 4,0\%. Hasil analisis menggunakan uji fisher's exact test 
diperoleh $p$ value 1,000 ( $p$ value $>0,05$ ) yang berarti ada hubungan yang tidak signifikan antara APGAR skor dengan status gizi stunting pada anak baduta. Analisis multivariat juga menunjukkan tidak ada hubungan yang signifikan antara jenis kelamin dengan kejadian stunting pada anak usia 6-23 bulan. Hasil analisis menggunakan uji regresi logistik ganda diperoleh $p$ value 1,000 ( $p$ value $>0,05$ ) yang berarti tidak ada hubungan signifikan antara tinggi jenis kelamin dengan status gizi stunting pada anak usia 6-23 bulan.

Hasil penelitian ini menunjukkan bahwa tidak adanya hubungan yang signifikan antara riwayat asfiksia dengan stunting anak baduta. Maka dapat disimpulkan bahwa anak baduta stunting bukan disebabkan oleh riwayat asfiksia.

\section{6) Hubungan Jenis Kelamin dengan Stunting}

Proporsi kejadian stunting pada anak baduta berjenis kelamin laki-laki yaitu sebanyak 48,0\%. Hasil analisis menggunakan uji chi square diperoleh $p$ value 0,571 ( $p$ value $>0,05$ ) yang berarti ada hubungan yang tidak signifikan antara jenis kelamin dengan status gizi stunting pada anak baduta. Analisis multivariat juga menunjukkan tidak ada hubungan yang signifikan antara APGAR skor dengan kejadian stunting pada anak usia 6-23 bulan. Hasil analisis menggunakan uji regresi logistik ganda diperoleh $p$ value 0,1 ( $p$ value $>0,05$ ) yang berarti tidak ada hubungan signifikan antara jenis kelamin dengan status gizi stunting pada anak usia 6-23 bulan.

Hasil penelitian ini menunjukkan bahwa tidak adanya hubungan yang signifikan antara jenis kelamin dengan stunting anak baduta. Maka dapat disimpulkan bahwa anak baduta stunting bukan disebabkan oleh jenis kelamin.

\section{e. Faktor Ekonomi}

Proporsi kejadian stunting pada anak baduta dengan pendapatan keluarga < UMR yaitu sebanyak 84,0\%. Hasil analisis menggunakan uji chi square diperoleh $p$ value 0,031 ( $p$ value $\leq 0,05$ ) yang berarti ada hubungan yang signifikan antara pendapatan keluarga dengan status gizi stunting pada anak baduta.

Hasil analisis menggunakan uji regresi logistik ganda diperoleh $p$ value 0,059 ( $p$ value $\leq 0,05$ ) yang berarti tidak ada hubungan yang signifikan antara pendapatan dengan status gizi stunting pada anak usia 6-23 bulan. Hal ini tidak sejalan dengan penelitian mengenai praktik pemberian makanan pendamping ASI (MP-ASI) bukan faktor risiko kejadian stunting pada anak usia6-23 bulan yang menunjukkan bahwa tingkat pendapatan yang rendah berhubungan dengan stunting ${ }^{18}$. Pendapatan keluarga yang memadai akan menunjang tumbuh kembang anak karena orang tua dapat menyediakan semua kebutuhan anak baik yang primer seperti makanan maupun kebutuhan sekunder. Tingkat penghasilan juga ikut menentukan ketersediaan pangan dalam keluarga.

\section{KESIMPULAN DAN SARAN}

\section{Keimpulan}

1. Berdasarkan hasil skrinning status gizi anak usia 6-23 bulan wilayah kerja Puskesmas I Wangon dari jumlah 1073 baduta, ditemukan sebanyak 291(27,12\%) mengalami stunting.

2. Berdasarkan kategori asupan zat gizi pada anak usia 6-23 bulan di wilayah kerja Puskesmas I Wangon :

a. Baduta stunting dengan asupan energi kurang $15(60,0 \%)$, asupan protein kurang $6(24,0 \%)$, asupan kalsium kurang $17(68,0 \%)$, asupan zink kurang $18(72,0 \%)$, dan asupan zat besi kurang 20(80,0\%).

b. Baduta status gizi normal dengan asupan energi kurang $11(44,0 \%)$, asupan protein kurang $6(24,0 \%)$, asupan kalsium kurang $20(80,0 \%)$, asupan zink kurang $15(60,0 \%)$ ,asupan zat besi kurang 18 (72,0\%).

3. Berdasarkan kategori riwayat infeksi pada anak usia 6-23 bulan di wilayah kerja Puskesmas I Wangon :

a. Baduta stunting sebanyak $8(32,0 \%)$ mengalami diare, dan sebanyak $11(44,0 \%)$ baduta mengalami ISPA.

b. Baduta normal sebanyak $4(16,0 \%)$ mengalami diare, dan sebanyak $4(16,0 \%)$ baduta mengalami ISPA.

4. Berdasarkan kategori faktor Ibu dan anak pada anak usia 6-23 bulan di wilayah kerja Puskesmas I Wangon :

a. Baduta stunting sebanyak $14(56,0 \%)$ memiliki Ibu dengan kategori TB pendek, $21(84,0)$ memiliki ibu yang tidak bekerja, $2(8,0 \%)$ riwayat $B B L R, 1(4,0 \%)$ mengalami asfiksia.

b. Baduta normal sebanyak $1(4,0 \%)$ memiliki Ibu dengan kategori TB pendek, 21(84,0\%) memiliki ibu yang tidak bekerja, $0(0,0 \%)$ riwayat $B B L R$, dan $0(0,0)$ mengalami asfiksia. 
5. Berdasarkan kategori pola pemberian makan pada anak usia 6-23 bulan di wilayah kerja Puskesmas I Wangon :

a. Baduta stunting sebanyak sebanyak $9(36,0 \%)$ menerapkan frekuensi makan tidak tepat, dan sebanyak 9(36\%) keragaman makanan dengan kategori kurang.

b. Baduta normal sebanyak 8(32,0\%) menerapkan frekuensi makan tidak tepat, dan sebanyak 5(20,0\%) keragaman makanan dengan kategori kurang.

6. Berdasarkan kategori sosial ekonomi pada anak usia 6-23 bulan di wilayah kerja Puskesmas I Wangon :

a. Baduta stunting sebanyak $21(84,0 \%)$ memiliki pendapatan keluarga $\leq U M R$

b. Baduta normal sebanyak $4(16,0 \%)$ memiliki pendapatan keluarga $\leq \mathrm{UMR}$

7. Determinan kejadian stunting pada anak usia 623 bulan di wilayah kerja Puskesmas I Wangon yaitu TB ibu $(p=0,017)$, sedangkan asupan energi, asupan protein, asupan kalsium, asupan zink, asupan zat besi, diare, ISPA, frekuensi makan, keragaman makanan, pendidikan, status BBL, nilai APGAR, jenis kelamin, pekerjaan ibu dan pendapatan keluarga tidak berhubungan dengan kejadian stunting.

\section{Saran}

Sebaiknya dilakukan advokasi berkaitan dengan intervensi dalam penanganan anak status gizi stunting karena saat ini yang dilakukan hanya untuk sasaran balita dengan status gizi buruk dengan indikator $\mathrm{BB} / \mathrm{U}$ dan $\mathrm{TB} / \mathrm{U}$, sedangkan $\mathrm{PB} / \mathrm{U}$ atau $T B / U$ belum ada intervensi nyata serta perlu dilakukan kegiatan guna meningkatkan pengetahuan responden tentang ASI dan susu formula dan juga gizi seimbang anak baduta karena masih banyak responden yang belum paham bagaimana teknik yang tepat dalam persiapan ASI ataupun susu formula.

\section{DAFTAR PUSTAKA}

1. Badan Penelitian dan Pengembangan Kesehatan Departemen Kesehatan RI. Laporan Riset Kesehatan Dasar (Riskesdas) 2013. Jakarta 2013

2. Badan Penelitian dan Pengembangan Kesehatan Departemen Kesehatan RI. Laporan Riset Kesehatan Dasar (Riskesdas) 2010. Jakarta 2010

3. Badan Penelitian dan Pengembangan Kesehatan Departemen Kesehatan RI. Laporan
Riset Kesehatan Dasar (Riskesdas) 2007. Jakarta 2007

4. Dinas Kesehatan Kabupaten Banyumas. 2016. Profil Kesehatan Kabupaten Banyumas 2016

5. Dinas Kesehatan Provinsi Jawa Tengah. 2016. Laporan Pemantauan Status Gizi Jawa Tengah 2016

6. Walker, S. P., Wachs, et al . 2011. Inequality in Early Childhood: Risk and Protective Factors for Early Child Development. The Lancet, 378, 1325-1338

7. Black, R. E., Victora, et al. 2013. Maternal and Child Undernutrition and Overweight in LowIncome and Middle-Income Countries. The Lancet, 382, 427-451.

8. Adair, L. S., Fall, C. H, et al. 2013.Associations of Linear Growth and Relative Weight Gain During Early Life with Adult Health and Human Capital in Countries of Low and Middle Income: Findings from Five Birth Cohort Studies . The Lancet, 382, 525-534.

9. WHO. 2014. Childhood Stunting: Challenges and Opportunities: Report of a Webcast Colloquium on the Operational Issues around Setting and Implementing National Stunting Reduction Agendas. 14 October 2013-Who Geneva.

10. WHO. 2007. Indicators for Assessing Infant and Young Child Feeding Practices. Conclusions of a consensus meeting held 6-8 November 2007 in Washington, DC, USA.

11. Kassa et al. 2016 .Appropriate complementary feeding practices and associated factors among mothers of children age 6-23 months in Southern Ethiopia. 2015. BMC Pediatrics (2016) 16:131. August 19. 2016

12. Rahayuh dkk, 2016. Faktor Risiko yang Berhubungan dengan Kejadian Pendek pada Usia 6-24 Bulan. Jurnal Kesehatan Masyarakat. ISSN 1858-1196. Semarang : Universitas Negeri Semarang

13. Bhargava, Alok. 2016. Protein and Micronutrient Intakes Are Associated with Child Growth and Morbidity from Infancy to Adulthood in the Philippines. The journal of nutrition. University of Maryland School of Public Policy, College Park, MD

14. Arisman. 2010. Buku Ajar Ilmu Gizi (GDDK). Jakarta: EGC

15. Pollard, Maria. 2012. ASI Asuhan Berbasis Bukti. Jakarta : Penerbit Buku Kedokteran EGC

16. Paudel R, et al. 2011. "Risk factors for stunting among children: a community based case control study in Nepal". Kathmandu Univ MedJ (KUMJ). 2011;10:18-24. 
17. Nasution, Darwin, dkk. 2014."Berat Badan Lahir Rendah (BBLR) dengan Kejadian stunting pada Anak Usia 6-24 bulan". Jurnal Gizi Klinik Indonesia.
18. Nai, Hildagardis M.E dkk. 2014." Praktik pemberian makanan pendamping ASI (MPASI) bukan faktor risiko kejadian stunting pada anak usia 6-23 bulan 